carefulness. This was particularly evident in his dealings with students, who held him in high affection and for whom no amount of work was a trouble to him. Besides being an excellent and sympathetic teacher and a delightful olleague, he had many sterling qualities; his modest manner, quiet humour, and kindly smile endeared him to all with whom he associated. It can truly be said of him that he spent himself gladly in the service of others. R.W. L.

\section{Sir Arthur Downes}

Sir Arthor Downes, who died on March 11, at his home on Mount Carmel, Haifa, Palestine, at the age of eighty-six years, had a long career in the public health service. $\mathrm{H}_{e}$ was educated at Shrewsbury School, University College, London, and the University of Aberdeen, where he graduated M.B., C.M. with honours in 1873 . He became M.D. in 1875, and took the diploma of public health, Cambridge, in 1877.

After serving as deputy medical officer for Shropshire, and medical officer of health for the Essex Combined Areas, 1879-99, Downes was made inspector in the old Local Government Board, rising to become its senior medical inspector. He represented that body on many occasions, and served on the Royal Commission on the Poor Laws, and on a number of departmental committees.

Sir Arthur Downes will be best remembered for the pioneer work he did on the effect of light in inducing certain chemical changes, upon protoplasm and micro-organisms, and upon the activity of enzymes, publishing several communications on these subjects between 1877 and 1886, alone or in association with T. P. Blunt, in the Chemical News, Proceedings of the Royal Society and Nature. Downes and Blunt showed that oxalic acid is completely oxidized and hydrogen peroxide is partially destroyed by insolation. In their "Researches on the Effect of Light upon Bacteria and other Organisms" in 1877, they found that light is inimical to the development of bacteria and micro-fungi, and under favourable conditions may wholly prevent development, the fitness of the culture liquid for growth being unimpaired, and they stated that this effect appeared to be associated with the actinic rays.

They carried this investigation a stage further in 1878 in their work "On the Influence of Light on Protoplasm". They tested the action of light upon Bacteria and Torulæ grown in test-tubes screened with different coloured glasses, the light-transmission of which was determined spectroscopically, and found that the action depends chiefly upon the blue and violet rays. Downes published another paper in 1886 on "The Action of Sunlight on Micro-Organisms", and in a letter in NATURE of the same year $(34,546)$ stated that the enzymes invertase, malt diastase, pancreatic diastase and trypsin, are all destroyed by insolation for a month.

Not inappropriately, Downes became a vicepresident of the Sunlight League; he was knighted in 1910, and held the Order of the Crown of Belgium. R. T. Hewlett.

\section{Sir Raymond Crawfurd}

WE regret to announce the death on March 9 at the age of seventy-two years of Sir Raymond Crawfurd, registrar of the Royal College of Physicians of London, consulting physician to King's College Hospital and fellow of King's College, London.

Raymond Henry Payne Crawfurd was born on November 9, 1865, at East Grinstead, where he afterwards became consulting physician to the dispensary. He was the son of the Rev. Walter Payne Crawfurd, and was educated at Winchester and New College, Oxford. He qualified M.B. in 1894 and M.D. in 1896 with a thesis on Graves's disease, on which he afterwards contributed an article to Quain's "Dictionary of Medicine" (1900). In addition to his position on the staff of King's College Hospital, to which he was appointed assistant physician in 1898, dean in 1900 and full physician in 1905, his two chief spheres of activity were Epsom College, where he was chairman of the Council for thirteen years, and the Royal College of Physicians, where he was successively Fitzpatrick lecturer (1911-12), examiner (1912-16), censor (1918), Harveian orator (1919) and registrar from 1925 until the time of his death.

Apart from his joint editorship with Dr. (now Sir Farquhar) Buzzard of the fourth edition of Burney Yeo's "Manual of Treatment" (1909), Crawfurd contributed little to the literature of modern medicine, but he took a scholarly interest in the history of his art, being secretary of the section of medical history in the International Congress of Medicine held in London in 1913 and afterwards president of the Section of the History of Medicine of the Royal Society of Medicine, in the formation of which he took an active part. In 1909 he published a work entitled "The Last Days of Charles II", and in 1911 and 1912 chose as the subjects of his Fitzpatrick lectures "The King's Evil"' and "Echoes of Pestilence in Literature and Art" respectively. Crawfurd was not only a fine scholar and an urbane and kindly physician, but also an excellent organizer and man of business whose loss it will be difficult to replace.

J. D. R.

WE regret to announce the following deaths :

Mr. Frederick J. Gould, author of many papers on moral education and world unity, who devoted his life to the promotion of social progress, on April 6, aged eighty-two years.

Prof. F. Mesnil, of the Pasteur Institute of Paris, member of the Section of Anatomy and Zoology of the Paris Academy of Sciences, aged seventy years.

Prof. Otto Naegeli, professor of internal medicine and director of the Medical Clinic in Zurich, known for his work on diseases of the blood, aged sixtyseven years.

Prof. D. W. Hering, emeritus professor of physics in New York University, on March 24, aged eightyeight years.

Mr. F. A. Molitor, consulting engineer of New York, known for his work in railroad engineering, on March 12, aged sixty-nine years. 